\title{
IMPORTANȚA RELIGIEI ÎN VIAȚA ADOLESCENŢILOR. O ABORDARE ȘTIINȚIFICĂ
}

\author{
Andrei Ovidiu Crișan*
}

\begin{abstract}
This assessment has been designed in order to underline the importance of religion in teenage years, based on psychology, sociology and pedagogy studies. The Church it is always challenged to prove its usefulness, therefore by this article we wanted to highlight the necessity of religion and spirituality in the lives of young people. Without Church it is nearly impossible for a society to be formed by harmony developed people and this fact it is strictly conditioned by the presence of religion and spirituality among the new generation.
\end{abstract}

Keywords: spirituality, Church, neurology, psychology, sociology, positive youth development, well-being.

\section{Preliminarii}

Indiferent de cultură, rasă, etnie sau gen, omul a considerat că fără religie este foarte dificil să se armonizeze cu aproapele și de asemenea, cu sine însuși. În ultimul timp, secularizarea a făcut ca problema religiei să devină din ce în ce mai discutabilă. Prin scoaterea religiei din societate și din viața de zi cu zi, „omul a creat diferite surogate sociale, psihologice, sociologice, religioase sau pseudo-religioase" , care nu pot să conțină aceleași „,instrumente ale devenirii” umane pe care le are religia. Astfel, omul, din dorința descătuşării față de unele elemente patologice ale religiei, a devenit autofag, prin rezecționarea și a trăsăturilor salutare ale acesteia. Prin urmare, este necesar ca religia, iar în cazul nostru credința ortodoxă, să își regăsească locul în educația și devenirea persoanei umane. De aceea, este imperioasă cunoașterea impactului pozitiv al religiei și spiritualitătii, mai ales în perioada adolescenței, perioadă de maximă metamorfozare din viața unui om.

\footnotetext{
* PhD Candidate, Faculty of Orthodox Theology at University "1 Decembrie 1918" in Alba Iulia.

${ }^{1}$ Ciprian Marius Cloșcă, Ortodoxia și Noile Mișcări Religioase, Iași, Edit. Lumen, 2009, p. 57.
} 
Așadar, în acest studiu înflorește întrebarea dacă religia și spiritualitatea pot să ofere un cadru pozitiv al dezvoltării viitorului adult? Sau, poate religia să fie benefică și în cazul unei societăţi secularizate? În ce măsură, religia poate să stopeze dezvoltarea unei societăţi?

Se vehiculează ideea că îndoctrinarea religioasă în perioada copilăriei, chiar și în credința ortodoxă, poate să cauzeze regresul intelectual, să descurajeze reușita pe plan științific, sau eșecul integrării în societate din punct de vedere economic. Pe parcursul acestui studiu pretindem că furnizăm o serie de răspunsuri în favoarea importanței religiei și spiritualității în edificarea unei personalități chiar în concordanță cu cerințele unei societăți seculare.

Este important de știut că acest studiu va aduce răspunsuri „empirice”, adică măsurabile, aflate „în proprietatea” științelor nerevelate, deoarece trebuie utilizate instrumentele științifice pentru a avea credibilitate dinspre lumea așa-zis științifică și seculară. Cunoașterea științifică este considerată de aproape un secol și jumătate adevărata cale de cunoaștere, nemaiâncăpând învățăturile religioase. Astfel, trebuie demonstrat de ce omul fără religie poate să-și riște existența? Și de ce este importantă religia în perioada de maximă dezvoltare a lui (adolescența), în perspectiva integrării eficiente în societate? Viziunea noastră nu este cea evoluționistă, care percepe religia ca pe un accesoriu al omului apărut la un moment dat în istorie, ci prezentăm religia ca pe o străduință a omului de a intra în comuniune cu Dumnezeu. Prin urmare, am ales să folosim cercetările unor oameni de știință (care par să fie evoluționiști, sau chiar atei) și să le ajustăm opticii creaționiste, păstrând obiectivitatea și rigoarea cercetării științifice. Din cele observate, în bibliografia folosită de noi, se încearcă reliefarea importanței religiei în viața adolescentului, însă informațiile nu sunt printre cele mai numeroase, ceea ce denotă o lipsă de preocupare din partea cercetătorilor pe acest segment. 


\section{Religiozitatea adolescenților la nivel mondial}

Faptul că adolescența este timpul auto-afirmării și edificării personalității, face ca sistemul de valori ambiental să fie pus la îndoială. Este perioada întrebărilor de tot felul, ceea ce reprezintă firescul lucrurilor. Sunt mulți factori care fac ca întrebările referitoare la credință să deterioreze religiozitatea în rândul adolescenților. $\mathrm{Nu}$ întrebarea despre existența lui Dumnezeu este punctul sensibil, ci perspicacitatea de a oferi răspunsuri pertinente. În felul acesta, argumentăm noi faptul că în lume, religiozitatea adolescenților diferă de la țară la țară. Unii ar spune că aceasta diferă în funcție de nivelul de trai ${ }^{2}$, ceea ce nu este cel mai bun argument, datorită faptului că cea mai dezvoltată țară din lume SUA, are o religiozitate a tinerilor net superioară în comparație cu statele vest europene.

Alt argument care are legătură cu religiozitatea este, libertatea de a alege. Unii spun că în țările în care libertatea de exprimare este mai solidă, religiozitatea este mai scăzută. Statele Unite ale Americii se dovedesc a fi un contra exemplu și față de această ipoteză. Prin urmare, în comparație cu alte state în care libertatea de expresie este „sfântă”, adolescenții americani se revendică aparținând unei secte sau religii în proporție de $85-87 \%$, și doar $13-15 \%$ se declară ne-religioși ${ }^{3}$. Spre

2 Laura H. Lippman and Julie Dombrowski Keith, The Demographics of Spirituality Among Youth: International Perspectives, în Eugene C. Roehlkepartian, Pamela Ebstyne King, Linda Wagener, Peter Benson (ed.), „The Handbook of Spiritual Development in Childhood and Adolescence", London, New Delhi, Sage Publications, 2006, p. 117; vezi și: Ronald Inglehart, P. Norris, Sacred and Secular: Religion and politics worldwide, Cambridge, Cambridge University Press, 2004.

3 Pamela Ebstyne King and Robert W. Roeser, Religion and Spirituality in Adolescent Development, în Richard M. Lerner, Laurence Steiberg (ed.), „Handbook of Adolescent Psychology: Individual Bases of Adolescent Development", vol. I, New Jersey, John Wiley \& Sons, 2009, p. 437. Pentru o mai detaliată caracterizare a religiozității în rândul adolescenților din SUA, vezi opera: Christian Smith, Melinda Denton, Soul searching: The religious and spiritual lives of American teenagers, New York, Oxford University Press, 2005. 
deosebire de SUA doar $20 \%$ dintre tinerii vest-europeni consideră că religia este foarte importantă, iar numai $19 \%$ cred și practică o religie oficială. Însă, 43 \% din tinerii europeni se consideră a fi „credincioși nepracticanți”, încadrându-se în fenomenul „spiritualității fără religie”.

Sondajul la nivel mondial arată o largă răspândire a credinței în Dumnezeu, chiar în rândul tinerilor, însă fără a acordarea vreunei importanțe a religiei în viața lor. SUA are cel mai mare procentaj al credinței tinerilor în Dumnezeu față de celelalte țări dezvoltate, demonstrat prin participarea tinerilor în cadrul organizațiilor religioase și prin importanța pe care o acordă religiei și spiritualității în viețile lor. Aproximativ $40 \%$ din adolescenții de 14 ani sunt implicați în activități religioase, în timp ce în alte țări sunt undeva la $25 \%{ }^{4}$. Aceste date demografice argumentează că religia nu este un impediment al bunăstării. Avem și alte exemple care edifică această ipoteză, atunci când ne gândim la regimurile totalitare, care dovedesc ducând om ură viscerală împotriva religiilor și care obişnuiau să „,păstreze” populația în sărăcie. Și astăzi, regimurile totalitare prezente în lume, au parte de un nivel de trai scăzut.

Cel mai bun exemplu este Korea de Nord, acolo unde ateismul comunist fac ca oamenii și implicit tinerii să se considere atei sau agnostici în proporție de $70 \%{ }^{5}$. Tot în Korea de Nord libertatea religioasă practic, nu există ${ }^{6}$. Prin urmare, religiozitatea nu cauzează sărăcie ci, mai degrabă este un substituent al bunăstării, un mijloc de înfruntare a nivelului de trai scăzut. De asemenea, dacă aparent găsim o slabă religiozitate în rândul țărilor puternic dezvoltate, se poate explica prin exagerarea productivității și consumerismului, sau prin iluzia că

${ }_{5}^{4}$ Laura H. Lippman și Julie Dombrowski Keith, art. cit., pp. 121-122.

5 Religious Adherents in Democratic Republic of (North) Korea, http://www.thearda.com/internationalData/countries/Country_123_2.asp (accesat la data de 16.04.2016).

Religious Freedom in Democratic Republic of (North) Korea,: http://www.thearda.com/internationalData/countries/Country_123_3.asp (accesat la data de 16.04.2016). 


\section{$15^{\text {th }}$ International Simposium on Science, Theology and Arts}

omul atât timp cât materia poate să îi ofere luxul și confortul aici pe pământ, nu mai are nevoie de o prezență în viaţa sa provenită din transcendent.

$\mathrm{Cu}$ excepția Estului Asiei și Vestului Europei, religiozitatea în rândul tinerilor este una crescută. Foarte mulți tineri atât din America, cât și din alte părți ale lumii, susțin că au o anumită relație cu Dumnezeu $^{7}$, ceea ce ne provoacă să concluzionăm că adolescenții și mai apoi tinerii, prezintă o religiozitate destul de uniformă, destabilizată doar de proliferarea secularizării în anumite zone sau state de pe glob. Prin urmare, numai intervenția omului în viața și mentalul adolescenților poate să diminueze prezența religiei în cadrul acestui segment de vârstă.

\section{Necesitatea religiei și a spiritualității în adolescență}

După cum am afirmat în introducerea acestui studiu, religia face parte din ființa omului, iar atunci când ea lipsește își creează surogate. Nevoia religiei nu o simte doar sufletul, ci și trupul, mai ales în perioada transformărilor de tot felul, aşa cum este adolescența. Așadar, omul are nevoie ca religia să fie o reală prezență în fiecare etapă a vieții lui, nu doar la început sau la sfârșitul ei. De aceea, în creștinism și nu numai, cele trei momente cheie ale vieții omului (nașterea, căsătoria, moartea), au o încărcătură religioasă aparte. $\mathrm{Cu}$ atât mai mult, Biserica trebuie să cuprindă oameni de toate vârstele, lucru care din păcate, nu se întâmplă astăzi, din cauza numărului limitat de tineri participanți la viața Bisericii.

\section{Implicațiile practicilor religioase și spirituale în dezvoltarea cerebrală a adolescenților}

Practicile religioase sau spirituale au un impact pozitiv asupra stării de bine, pentru că antrenează funcțiile psihologice cum ar fi reglarea activității emoționale. Practica meditaţiei este asociată cu

\footnotetext{
${ }^{7}$ Pamela Ebstyne King și Robert W. Roeser, Religion and Spirituality..., p. 441.
} 
activarea corticală prefrontală ${ }^{8}$. Cortexul prefrontal are legătură cu exprimarea personalității, luarea deciziilor sau comportamentul în societate, iar disfuncționalitatea acestei părți conduce la dereglări grave ale psihicului, cu repercusiuni asupra comportamentului în societate ${ }^{9}$. Erik Erikson afirma în urmă cu mai bine de o jumătate de veac, că religia este una dintre problemele centrale ale adolescenței, mai ales în ceea ce privește dezvoltarea procesului identității ${ }^{10}$. Acest lucru se poate vedea și la nivel cerebral, unde poate cea mai dramatică schimbare la nivelul creierului este apariția materiei albe, care cuprinde tipuri variate de celule, care, la rândul lor, înconjoară neuronii și le influențează activitatea.

Adolescența târzie este atunci când cortexul frontal, partea creierului care se ocupă, cu rațiunea, luarea deciziilor, sau conceptualizarea abstractului este supusă la maxim dezvoltării și remodelării. Aceasta este de asemenea, timpul devenirii spirituale, autorealizării și dezvoltarea însușirilor personale cum ar fi: competența, încrederea, relaționarea, caracterul și preocuparea față de aproapele ${ }^{11}$. Chimismul cerebral este quasi influențat de practicile religioase și spirituale mai ales în perioada adolescenței, atunci când se pun bazele biologice ale comportamentului social. Cercetătorii au găsit un hormon numit oxitocină care acționează ca un neurotransmițător din creier, fiind

${ }^{8}$ Heather L. Urry, Robert W. Roeser, Sara W. Lazar, şi Alan P. Poey, Prefrontal Cortical Activation during emotion regulation. Linking Religious/Spiritual Practices with well-being, în Amy Eva Alberts Warren, Richard M. Lerner, Erin Phelps (ed.), „Thriving and Spirituality Among Youth: Research Perspectives and Future Possibilities", New Jersey, JohnWiley \& Sons, 2012, p. 21.

${ }^{9}$ Michael Koenigs, The role of prefrontal cortex in psychopathy, în „Reviews in the Neurosciences", vol. 23, issue 3, jun. 2012, p. 253.

${ }^{10}$ Cf. Erik Erikson, Childhood and society, New York, Norton, 1950; Idem, Identity, youth, and crisis, New York, Norton, 1968.

${ }^{11}$ R, Lerner, M. Fisher, R. A. Weinberg, Toward a science for and of the people: Promoting civil society through the application of developmental science, în „Child Development", vol. 71, issue 1, 2000, p. 13-16. 


\section{$15^{\text {th }}$ International Simposium on Science, Theology and Arts}

eliberată direct în fluxul sanguin și sintetizată în hipotalamus ${ }^{12}$. Cantitatea ridicată de oxitocină în sistemul nervos central și în lichidul cefalorahidian, a fost asociată cu comportamentul afiliativ, iar cea scăzută cu agresiunea și anxietatea ${ }^{13}$. Cercetătoarea Elena Grigorenko afirmă că „spiritualitatea fiind conectată cu afilierea, este, cel puțin parțial, fundamentată pe proprietățile funcționale ale oxitocinei ${ }^{14 \%}$. Prin urmare, disfuncționalitatea „religiosului și spiritului” în persoana umană se răsfrânge asupra naturii chimice a acestuia.

Practicarea medației pentru mai puțin de două luni conduce la schimbări în structura creierului, dând credibilitate ipotezei că dezvoltarea pozitivă a tinerilor se poate modela și că intervențiile bazate pe contemplație, pot fi considerate moduri eficace de a ajuta indivizii cu un nivel scăzut al PYD (Positive Youth Development) să meargă într-o direcție pozitivă $\breve{1}^{15}$. Putem spune că ceea ce se întâmplă astăzi cu tinerii, este cu siguranță, din lipsa meditației, rugăciunii, credinței și speranței în Dumnezeu, iar interesant este că situația poate să fie explicată și științific, iar Biserica are datoria să atragă atenția că societatea umană nu poate să continue în situația aceasta.

Dezvoltarea pozitivă a tinerilor despre care am vorbit mai sus, ar putea stimula creșterea IQ-ului cu 6 puncte, însă doar la adolescenții de sex masculin. Această ipoteză a fost lansată datorită constatării faptului că adolescenții cu un nivel scăzut al PYD, au coeficientul de inteligență în medie cu 6 unități în minus în comparație cu cei care prezintă un PYD

${ }^{12}$ H. K. Caldwell, W. S. Young, Oxytocin and vasopressin: Genetics and behavioral Implications, în „Handbook of neurochemistry and molecular neurobiology: Neuroactive proteins and peptides" A. Lajtha \& R. Lim (Eds), Berlin, Springer, 2006, pp. 574-575.

${ }^{13}$ M. Kosfeld, M. Heinrichs, P. J Zak, U. Fischbacher, \& E. Fehr, Oxytocin increases trust in humans, în „Nature”, Nr. 435, 2005, p. 673-674.

14 Elena L. Grigorenko, Closeness of All Kinds. The Role of Oxytocin and Vasopressin in the Physiology of Spiritual and Religious Behavior, în „Thriving and Spirituality...", p. 46-47.

${ }^{15}$ Sara W. Lazar, Neural correlates of Positive Youth Development, în „Thriving and Spirituality...”, p. 83. 
ridicat. Întrebarea se pune dacă structura creierului este influențată de PYD sau invers? ${ }^{16}$ La această întrebare este greu de găsit un răspuns rezonabil, așa cum este dificil să tragem o concluzie referitoare la relaționarea între religiozitate şi coeficientul de inteligență la nivel mondial. Tendința de a afirma că oamenii religioși au un IQ scăzut nu este relevantă. De exemplu în țările cu un nivel scăzut al educaţiei persoanele religioase au un nivel mai ridicat al inteligenței datorită capacității religiei de a deveni „furnizor” al dorinței cunoașterii și problematizării, antrenând astfel inteligența. Oricum inteligența este doar una dintre valorile umane, iar religia poate să stimuleze mult mai multe facultăți ale omului care să-l ajute în devenirea lui personală.

$\mathrm{Ca}$ o concluzie a acestui subcapitol al studiului nostru putem spune că Dumnezeu a creat o armonie în chimismul omului, care se dovedește că are nevoie de relaţia cu Dumnezeu, nu doar pentru sănătatea sufletului ci și a trupului, care în perioada adolescenței, îi sunt necesare religia și spiritualitatea în perspectiva unei persoane care, poate susține o societate mai trainică. Conform bibliografiei studiate de noi, afirmăm că prin măsurătorile cu ajutorul RMN-ului dar și datorită sondajelor făcute de marile universități ale lumii, angajarea în activități religioase și spirituale, cum ar fi rugăciunea și meditația se poate corela cu creșterea densității materiei cenușii a unei părți din creier care controlează emoțiile și autorealizarea sau autoreglarea. Aceste cercetări confirmă importanţa la nivel biologic a spiritualităţii și dezvoltării pozitive a tinerilor ${ }^{17}$.

\footnotetext{
${ }^{16}$ Tomas Paus, Gabriel Leonard, Jacqueline V. Lerner, Richard M. Lerner, Michel Perron, G. Bruce Pike, Louis Richer, Roberto Toro, Suzanne Veillette, şi Zdenka Pausova, Positive Youth Development and age-related changes in cortical thickness during adolescence, în „Thriving and Spirituality...”, p. 72.

${ }^{17}$ Pamela Ebstyne King, Afterword, în „Thriving and Spirituality...”, p. 336.
} 


\section{Religia și importanța ei în dezvoltarea psiho-socială a adolescenților}

Umanitatea pare să fi ajuns astăzi la o stare de privativism care, din nefericire nu de diferențiază prea mult de primitivism. Acest lucru se întâmplă mai ales, în societățile dezvoltate unde individualismul cauzat de preocuparea omului față de materie, conduce la alienarea societății și la incapacitatea de integrare în societate a acestuia. Una din cauzele acestei stări este lacunara preocupare față de religie a adolescenților. În cele ce urmează, dorim să o analizăm o serie de date prin care să arătăm de ce religia poate să aducă un aport pozitiv, chiar pentru satisfacerea idealurilor unei societăţi seculare sau ne-religioase.

Erik Erikson, psihologul despre care am mai amintit în acest studiu a fost interesat de relaţionarea obiectivă între persoane (ego), mediile sociale și culturale ale acestora și implicațiile acestor relații persoană - context în dezvoltarea identității psihologice. Prin urmare, atât pentru Erikson cât și pentru Fowler, religia a fost conceptualizată ca o instituție care confirmă și susține speranțele indivizilor pe parcursul vieții. Religia nu furnizează doar o viziune asupra lumii transcendente, convingeri morale, și norme de comportament, ci tradițiile religioase de asemenea, încorporează aceste norme ideologice într-o comunitate de credincioși care pot avea rolul de modele pentru tineri ${ }^{18}$. Iată că religiile tradiționale reprezintă modalitățile cele mai corecte de furnizare a modelelor pentru tineri și singure să construiască o comunitate morală. Însă, media a adus o variantă înlocuitoare a lor prin prezentarea de noi modele și norme „morale”, mai savurabile în comparație cu anumite constrângeri ale comunităților religioase. Prin urmare, asistăm la o nouă modalitate de formare a identității tinerilor, una nemaiîntâlnită până acum.

${ }^{18}$ Erik Erikson, Identity, youth, and crisis, New York, Norton, 1968; James Fowler, Stages of faith: The psychological quest for human meaning, San Francisco, Harper, 1981, apud Pamela Ebstyne King și Robert W. Roeser, Religion and Spirituality..., p. 448. 
Faptul că tinerii și în cazul nostru adolescenții, obțin o anumită relaționare cu transcendentul în sensul de conexiune cu ceva de dincolo de ei înșiși, ajută la edificarea personalității și identității. Această experiență a transcendenței, poate să motiveze o creștere a angajamentului pentru a contribui la bunăstarea lumii de dincolo de ei ${ }^{19}$.

În încercarea de a găsi o serie de trăsături, prin care să se evidențieze importanța sau capacitatea unei persoane de a se face utilă societăţii, psihologii au recurs la asocierea a trei cuvinte: Great LoveCompassion și care este considerată cea mai fină expresie a relației noastre cu noi înșine dar și cu ceilalți ${ }^{20}$, sau „fundamentul, procesul și scopul sănătătii psihologice și plenitudinii ${ }^{21}$ ". Prin măsurătorile făcute de psihologi, s-a demonstrat că persoanele afiliate unei religii și în special cei care au avut parte de o educație religioasă solidă în tinerețe, au obținut scoruri superioare în comparație cu oamenii nereligioși ${ }^{22}$. Prin urmare, religiile tradiționale sunt pilonii de nezdruncinat pentru ca societatea umană să poată supraviețui, iar perioada de sedimentare a GLC este adolescența.

Pe de altă parte, cercetările au demonstrat că relaționarea personală și virtuțile morale au căpătat un loc din ce în ce mai important în viziunea despre spiritualitate a tinerilor, în perioada studenției, iar succesul este, în viziunea lor legat de aceste virtuți morale ${ }^{23}$. Așadar, este greu ca o societate, fie ea capitalistă sau seculară, să poată prospera fără cultivarea acestor virtuți în perioada adolescenței. Ca o societate să rămână sănătoasa are nevoie ca persoanele care o compun să simtă că au

\footnotetext{
${ }^{19}$ Pamela Ebstyne King, op. cit., p. 451.

20 Amy Eva Alberts Warren, Strengthening human potential for GreatLoveCo,,mpassion through Elaborative Development, în „Thriving and Spirituality...”, p. 94.

${ }^{21}$ Aura Glaser, A call to compassion: Bringing Buddhist practices of the heart into the soul of psychology, Berwick, Nicolas-Hays, 2005, p. 11-12.

${ }^{22}$ Amy Eva Alberts Warren, art. cit., p. 114-115.

${ }^{23}$ Jenni Menon Mariano, Robert W. Roeser, Paula Taylor Greathouse, şi Sonia S. Issac Koshy, Religious adolescents' views of success and spirituality, în „Thriving and Spirituality...”, p. 198-199.
} 
un sens al existenței și atitudini pozitive. De altfel, religiozitatea și spiritualitatea au fost asociate, cu promovarea sensului persoanei și atitudinilor pozitive în rândul tinerilor ${ }^{24}$.

Câțiva cercetători în cadrul psihologiei au analizat implicațiile religiei și spiritualităţii la nivelul celor $3 \mathrm{H}$ (Head, Heart și Hands) și au ajuns la concluzia că dezvoltarea pe plan religios și spiritual se poate suprapune pe dezvoltarea pozitivă a tinerilor la nivel cognitiv, afectiv și comportamental $^{25}$.

În general, credința și implicarea pe plan religios, s-a descoperit că exercită efecte salutare asupra funcționării psihologice a adolescenților în varii domenii, cum ar fi: performanța academică, bunăstarea subiectivă, stima de sine, implicarea pe plan civic precum și adoptarea unui stil de viaţă sănătos. Adolescenții religioși suferă de mai puţine simptome de anxietate sau depresie, prezintă un risc mai mic de suicid, resping sexul promiscuu sau premarital și nu sunt predispuşi la adoptarea unui comportament delincvent prin consumarea de droguri sau alcool $^{26}$. De asemenea, adolescenții care se expun frecvent conținutului religios (citirea, ascultarea, sau vizionarea informaţiilor religioase), au o probabilitate redusă de a adopta practici antisociale, a încuraja violența sau chiar a deveni victima acesteia ${ }^{27}$.

Adolescența, cu propriile schimbări în gândire și simţire, este primul prilej pentru tineri, de a se expune sau angaja în dialoguri despre idei și filosofii care au legătură cu întrebări existențiale despre identitate, scop, și sens, iar mentorii spirituali pot să primească un statut important

24 Selcuk Sirin, Mona Abo-Zena și Hala Shehadeh, Contributions Despite Challenges: Exploring Positive Youth Development Among Muslim American Youth, în „Thriving and Spirituality...”, p. 240.

${ }^{25}$ Pamela Ebstyne King, Afterword, în op. cit., p. 337.

${ }^{26}$ Lisa Miller, Brien Kelley, Relationships of Religiosity and Spirituality with Mental Health and Psychopathology, în Raymond F. Paloutzian, Crystal L. Park (ed.), „Handbook of the psychology of religion and spirituality”, New York, The Guilford Press, 2005, p. 467.

${ }^{27}$ Pamela Ebstyne King și Robert W. Roeser, Religion and Spirituality..., p. 464. 
în viețile tinerilor ${ }^{28}$. Prin urmare, este nevoie ca instituțiile religioase să ofere persoane capabile de a purta aceste dialoguri cu tinerii, care se află în cea mai sensibilă perioadă a vieții, adolescența.

\section{Concluzii}

Societatea umană are nevoie ca membrii ei să se dezvolte armonios, iar religia și spiritualitatea sunt două intrumente de care această dezvoltare are mare nevoie. Din datele folosite în acest studiu, reiese că trupul omului resimte o sete după comuniunea cu Dumnezeu, chiar în perioada adolescenței, cu toate că este perioada frământărilor și dubiilor în materie de credință. Corpul uman simte nevoia relaționării cu Creatorul, iar dacă nu se materializează aceasta prin rugăciune, meditație, reflectare la viața veșnică, etc., în timpul adolescenței, rămân sechele la nivel psiho-somatic, care pot provoca disfuncționalități cu repercusiuni asupra propriei persoane dar și asupra comunității din care face parte, sau societății în general.

Majoritatea cercetătorilor din cadrul psihologiei, pedagogiei sau sociologiei, din motive de neînțeles, nu au scos la lumină faptul că adolescenții au nevoie de religie, în perspectiva unei societăți mai sănătoase, iar cei care au făcut-o, sunt aproape toți citați în cadrul acestui articol. Considerăm că reprezentanții acestor științe mai sunt încă tributari marilor gânditori atei precum Freud, Marx, sau Nietzsche.

Viitorul unei societăți, este total incert, dacă nu sunt luate în calcul religia și spiritualitatea în dezvoltarea pozitivă a tinerilor. Datele inserate în acest articol arată că numai folosind aceste două instrumente, viitorul adult poate participa la prosperitatea unei societăți. Astfel, el devine mult mai responsabil și implicat în viața socială și chiar în cea economică.

Prin urmare, Biserica Ortodoxă trebuie să își arate utilitatea pe plan social, prin impactul pe care îl poate avea în viața viitorilor adulți. Mai întâi este nevoie să explice chiar și știinţific, aportul pozitiv adus

${ }^{28}$ Ibidem, p. 469. 
persoanei umane, dacă cunoașterea științifică este quasi-credibilă în zilele noastre.

\section{Bibliografie}

1. Aura Glaser, A call to compassion: Bringing Buddhist practices of the heart into the soul of psychology, Berwick, Nicolas-Hays, 2005.

2. Caldwel, H. K., W. S., Young, Oxytocin and vasopressin: Genetics and behavioral Implications, în A. Lajtha \& R. Lim (Ed), „Handbook of neurochemistry and molecular neurobiology: Neuroactive proteins and peptides" Berlin, Springer, 2006.

3. Cloșcă, Ciprian Marius, Ortodoxia și Noile Mișcări Religioase, Iași, Edit. Lumen, 2009.

4. Elena L. Grigorenko, Closeness of All Kinds. The Role of Oxytocin and Vasopressin in the Physiology of Spiritual and Religious Behavior, în Amy Eva Alberts Warren, Richard M. Lerner, Erin Phelps (ed.), „Thriving and Spirituality Among Youth: Research Perspectives and Future Possibilities”, New Jersey, JohnWiley \& Sons, 2012.

5. Erik Erikson, Identity, youth, and crisis, New York, Norton, 1968.

6. Idem, Childhood and society, New York, Norton, 1950.

7. Inglehart, Ronald, P. Norris, Sacred and Secular: Religion and politics worldwide, Cambridge, Cambridge University Press, 2004.

8. Fowler, James, Stages of faith: The psychological quest for human meaning, San Francisco, Harper, 1981.

9. King, Pamela Ebstyne, and Robert W. Roeser, Religion and Spirituality in Adolescent Development, în Richard M. Lerner, Laurence Steiberg (ed.), „Handbook of Adolescent psychology: Individual Bases of Adolescent Development", vol. I, New Jersey, John Wiley \& Sons, 2009.

10. King, Pamela Ebstyne, Afterword, în Richard M. Lerner, Laurence Steiberg (ed.), „Handbook of Adolescent psychology: Individual Bases of Adolescent Development”, vol. I, New Jersey, John Wiley \& Sons, 2009.

11. Koenigs, Michael, The role of prefrontal cortex in psychopathy, în „Reviews in the Neurosciences”, vol. 23, issue 3, jun. 2012.

12. Kosfeld, M., Heinrichs, M., Zak, P. J, Fischbacher, U., \& Fehr, E., Oxytocin increases trust in humans, în „Nature”,Nr. 435, 2005.

13. Lazar, Sara W., Neural correlates of Positive Youth Development, Amy Eva Alberts Warren, Richard M. Lerner, Erin Phelps (ed.), „Thriving and Spirituality Among Youth: Research Perspectives and Future Possibilities", New Jersey, JohnWiley \& Sons, 2012. 
14. Lerner, R, Fisher, R. A. Weinberg, Toward a science for and of the people: Promoting civil society through the application of developmental science, în „Child Development”, vol. 71, issue 1, 2000.

15. Lippman, Laura H. și Keith, Julie Dombrowski, The Demographics of Spirituality Among Youth: International Perspectives, în Eugene C. Roehlkepartian, Pamela Ebstyne King, Linda Wagener, Peter Benson (ed.), „The Handbook of Spiritual Development in Childhood and Adolescence”, London, New Delhi, Sage Publications, 2006.

16. Mariano, Jenni Menon, Robert W. Roeser, Paula Taylor Greathouse, și Sonia S. Issac Koshy, Religious adolescents' views of success and spirituality, în Amy Eva Alberts Warren, Richard M. Lerner, Erin Phelps (ed.), „Thriving and Spirituality Among Youth: Research Perspectives and Future Possibilities", New Jersey, JohnWiley \& Sons, 2012.

17. Miller, Lisa, Kelley, Brien, Relationships of Religiosity and Spirituality with Mental Health and Psychopathology, în Raymond F. Paloutzian, Crystal L. Park (ed.), „Handbook of the psychology of religion and spirituality”, New York, The Guilford Press, 2005.

18. Pamela Ebstyne King, Afterword, în Amy Eva Alberts Warren, Richard M. Lerner, Erin Phelps (ed.), „Thriving and Spirituality Among Youth: Research Perspectives and Future Possibilities", New Jersey, JohnWiley \& Sons, 2012.

19. Paus, Tomas, Leonard, Gabriel, Lerner, Jacqueline V., Lerner, Richard M., Perron, Michel, Pike, G. Bruce, Louis Richer, Roberto Toro, Suzanne Veillette, și Zdenka Pausova, Positive Youth Development and age-related changes in cortical thickness during adolescence, în Amy Eva Alberts Warren, Richard M. Lerner, Erin Phelps (ed.), „Thriving and Spirituality Among Youth: Research Perspectives and Future Possibilities", New Jersey, JohnWiley \& Sons, 2012.

20. Sirin, Selcuk, Mona Abo-Zena și Hala Shehadeh, Contributions Despite Challenges: Exploring Positive Youth Development Among Muslim American Youth, în Amy Eva Alberts Warren, Richard M. Lerner, Erin Phelps (ed.), „Thriving and Spirituality Among Youth: Research Perspectives and Future Possibilities", New Jersey, JohnWiley \& Sons, 2012.

21. Smith, Christian, Melinda Denton, Soul searching: The religious and spiritual lives of American teenagers, New York, Oxford University Press, 2005.

22. Urry, Heather, Roeser, Robert W., Lazar, Sara W., și Poey, Alan P., Prefrontal Cortical Activation during emotion regulation. Linking Religious/Spiritual Practices with well-being, în Amy Eva Alberts Warren, 
Richard M. Lerner, Erin Phelps (ed.), „Thriving and Spirituality Among Youth: Research Perspectives and Future Possibilities", New Jersey, JohnWiley \& Sons, 2012.

23. Warren, Amy Eva Alberts, Strengthening human potential for Great LoveCompassion through Elaborative Development, în Amy Eva Alberts Warren, Richard M. Lerner, Erin Phelps (ed.), „Thriving and Spirituality Among Youth: Research Perspectives and Future Possibilities”, New Jersey, JohnWiley \& Sons, 2012.

\section{Adrese web}

- Religious Adherents in Democratic Republic of (North) Korea,:http://www.thearda.com/internationalData/countries/Country_123 2.asp (accesat la data de 16.04.2016).

- ReligiousFreedom in Democratic Republic of (North) Korea,: http://www.thearda.com/internationalData/countries/Country_123 3.asp (accesat la data de 16.04.2016). 